\title{
Utilizing WebQuests for Enhancing Teaching Skills of Saudi Pre-Service Teachers of English as a Foreign Language
}

\author{
Ali Alsagheer A. Mohammmad ${ }^{1} \&$ Mohammed Albahiri $^{1}$ \\ ${ }^{1}$ King Khalid University, Saudi Arabia \\ Correspondence: Mohammed Albahiri, King Khalid University, Asir - Abha 61421, P. O. Box 960, Saudi Arabia. \\ E-mail: malqarni@kku.edu.sa
}

Received: July 26, 2020

Accepted: September 9, 2020

Online Published: September 23, 2020

doi:10.5539/ijel.v10n6p254

URL: https://doi.org/10.5539/ijel.v10n6p254

\begin{abstract}
Purpose: There is need to focus on extensive use of technology in teaching and learning process, since the teachers are provided with well-organized WebQuests that are beneficial for developing effective teaching skills. The study aims to investigate the extent of the effects of WebQuests on the teaching skills and performance of pre-service teachers of English at the College of Education of King Khalid University. Methodology: The study sample, which included 35 students of the general diploma in English, were divided into two groups: experimental and control. The members of the control group were supervised in the traditional way during their teaching practice, and the members of the experimental group were given WebQuests so that they could surf the internet under the guidance of their supervisor and find the information they needed about teaching skills. The teaching performance of the teachers of both groups was assessed via a teaching performance observation form. The data collected through classroom observation was analyzed using SPSS. The differences between the teachers of both the groups in terms of the teaching skills were calculated using Mann-Whitney U test. Findings: Statistically significant differences were found in the rank means of the participants of the control and the experimental groups regarding their lesson planning and teaching skills. The results were favorable for the teachers of the experimental group; however, no significant difference was found between the scores of the experimental and the control groups in terms of lesson evaluation skills. Originality: The use of WebQuests significantly enhances the teaching skills of the students of the general diploma in English.
\end{abstract}

Keywords: English, pre-service teachers, students, teaching performance skills, WebQuests

\section{Introduction}

Remarkable changes have been adopted since the past few years, in pre-service teacher preparation frameworks since the last few decades. The major shifts were based on the development of the main epistemological trends in the educational research field, particularly, interpretative views and positivism. Traditionally, it is debated that theoritical knowledge about teaching could be transmitted to student teachers. According to Cochran-Smith (2016), teaching knowledge is assumed to be applicable in any teaching context leading to the emergence of the transmission model of pre-service teacher preparation. Here, the learning to teach is confined to learning related to teaching. Therefore, a large set of instructional practices are underpinned by the transmission model (Abdullah, 2018). Kim (2011) attempted to cope up with recent teaching demands by promoting teacher-learners to understand teaching through learner-centered activities. The learning of pre-service teachers is based on formulating theories through practices, rather than translating theories into practices (Abdullah, 2018). Nowadays, teachers find difficulty in carrying out their rules among diverse students and language classrooms (Haddix, 2017). The main focus is on teachers' preparation to develop their abilities and deal constantly changing enrolments and communities and unpredictable nature of language classroom (Yuksel, 2014).

Traditional mechanisms of conducting the practicum course do not help much in accomplishing the expected objectives. In recent years, the use of internet has resulted as a source of information explosion, and the future of a country is shaped and based on the appropriate and timely use of the internet. Information and communication technologies, along with electronic authorship, play an important role in shaping the successful future of communities (Bergen, 2001). The internet is further useful to enhance and upgrade the field of education. The teaching process is greatly affected by the internet, as it allows teachers and supervisors to enhance their skills by instilling the experiences and expertise of teachers working across the globe. Previous studies have emphasized 
on the facilities gained through internet, which include online access to sound, data sources, graphic, and lesson plans for the researchers and educators (Akkoyunlu \& Y1lmaz, 2005; Megala \& Madhumathi, 2016).

WebQuests are considered a common online interactive device. They have become a popular way to integrate the use of the internet into curricula designed for teachers. Maddux and Cummings (2007) scanned the first 1,000 Google hits and reviewed the recent introductory textbooks on information technology. The results revealed WebQuests as the most used tool by the teachers and regarded it as supportive in the teaching practices. This device provides students with an opportunity to use several internet sources, and it is also known as an interactive learning exercise (Aydin, 2016). Indeed, WebQuests are considered as the most structured, promising, and accessible application in the field of online education. A WebQuest involves inquiry-oriented activities and almost all the information used by learners is drawn from the Web. The concept of WebQuests has been designed to use learners' time effectively, with an aim to make effective usage of the existing information rather than seeking additional knowledge. The prime concern of the application is to stimulate critical thinking of the learner in terms of synthesis, analysis and evaluation.

Practicum is considered as one of the important courses in the educational program of the King Khalid University. This course is based on the philosophy that the effective education of teachers is a top priority in the education program of pre-service teachers. However, the pre-service teachers face many challenges; for instance, they do not receive enough training due to short term visits of supervisors which makes the training ineffective as they lack mastering the required teaching skills necessary for a qualified and effective teacher. On the other hand, faculty staff members, who are supposed to pay intensive and regular visits to the cooperating schools are also overloaded with other tasks, such as lectures, meetings, and administration, which accounts for their absence. Such challenges have indirectly affected the teaching skills of pre-service teachers.

Majority of pre-service teachers finish their training with a reasonable understanding of many teaching/learning concepts and techniques, as demonstrated in the research by Sadik, Leftwich and Nadiruzzaman (2017). Furthermore, in practicum, it is not useful to consider the supervisor as the sole source of information in these times of knowledge explosion. Instead, trainees should be trained to become autonomous in the required knowledge acquisition. The low level of teaching skills of pre-service teachers highlighted the need to conduct this study, which aims to find a solution to this problem with the help of WebQuests. The current study aims to study the impact of WebQuests on the development of teaching performance skills in the pre-service teachers.

The study results are significant, as they contribute to the enhancement of the teaching skills of pre-service teachers of English as a foreign language (TEFLers). It is likely to contribute positively to the extensive use of technology in teaching as well as the learning process. The findings of this study favor learner-centered teaching practices since the teachers are provided with well-organized WebQuests, which are beneficial for developing effective teaching skills. They also present a teaching performance observation sheet that helps in the evaluation of the classroom practices adopted by the teachers. The main objectives of this study are as follows;

1) Investigate the impact of WebQuests on the development of teaching performance skills in the pre-service teachers

2) Explain the enhancement of teaching skills of English pre-service teachers

3) Evaluate classroom practices adopted by the teachers considering WebQuest that is beneficial to develop effective teaching skills

The research question of this study is as follows:

1) What is the impact of utilizing WebQuests in the general diploma practicum on development of the performance skills of pre-service TEFLers'?

\section{Review of Literature}

Educating teachers about effective teaching methodologies is a difficult challenge for teaching supervisors (Richards, 2008; Skott, 2015). Practicum is one of the educational courses that help teachers acquire teaching expertise. In the College of Education of King Khalid University, the practicum is an integral part of the preliminary teacher training program; with the help of practicum, teachers are made aware of the techniques of classroom teaching. Moreover, this course helps teachers to develop important professional knowledge and thus plays a significant role in helping them pursue a successful teaching career. Soft skills, like working with fellow teachers, solving problems independently, and developing a professional attitude, are also inculcated in teachers by this course (Coffey \& Lavery, 2015).

Dodge created WebQuests in 1995 which refers to the time when the use of internet was not common across the 
world. It began with the increase in internet access in university labs to explore effective ways of integrating technology into classroom instruction (Schweizer \& Kossow, 2007). In response to this quest, WebQuest was launched by Dodge to integrate the Web in classroom learning through the development of learning activities for pre-service teachers (Schweizer \& Kossow, 2007). While conducting an online search of posted WebQuests, a teacher is likely to find many activities related to different topics of subjects. Quality WebQuests have certain critical long-term and short-term attributes (Dodge, 1995; Irafahmi, 2016). Table 1 shows the critical attributes: an introduction, information sources, a task, guidance, process, and conclusion (Table 1). Motivational elements and group activities are some of the attributes that are usually included in WebQuests. Moreover, WebQuests can be implemented either within a single discipline or could be used in an interdisciplinary manner.

There is a significant amount of literature related to the effectiveness of the implementation of WebQuests in education in general and teacher education in particular. Wang and Hannafin (2008) stated that WebQuests had been widely used by teachers during the past decade with the sole aim of the integration of technology with teaching and learning. Adell, Mengual-Andres and Roig-Vila (2015) observed WebQuests in the didactically supported proposals that benefit from the use of different internet sources. This approach helps facilitate technological literacy within the classroom setting (Kachina, 2012). In addition, the introduction of student-centered activities by WebQuests helps transform a teacher-centered learning environment into a student-centered learning experience (Adell et al., 2015). Previous studies have explained that WebQuests have gone through various transformations considering the components, complexity, reorganizations, and use of constructivist strategies after becoming an important part of the educational sector (Abbitt \& Ophus, 2008; Kachina, 2012; Adell et al., 2015).

According to Alshumaimeri and Almasri (2012), WebQuests are widely used for developing different foreign language skills in students. Such as, one of the major tasks in WebQuests is that students are allowed to put forward their views either in written or oral form while focusing on different accents and forms of English expressions (Gaskill, McNulty, \& Brooks, 2006). Therefore, it is believed that students can be taught to search for information from different web sources by using WebQuests and that this improves their reading and writing skills.

In the current era, students' role and responsibilities have changed significantly on account of the change in their perception of teachers. It is generally believed that traditional teachers are the major sources of knowledge, which is then transferred to their students. However, the recent improvements in instructional technologies have changed the role of teacher in the classroom. Nowadays, the teacher trainers implement the WebQuest model with pre-service teachers to develop their technology integration skills. Scaffolding, such as this is known for its role in helping pre-service teachers and in supporting the gradual acquisition of skills and knowledge for better understanding of underlying assumptions (Wang \& Hannafin, 2008; Kushins, 2015).

Yang et al. (2011) introduced WebQuests for the training of pre-service special education teachers in Singapore. Around 75 pre-service special education teachers were included in the study; they had to answer the questionnaire and share their experiences about WebQuests developed by the course instructor. The results showed that teachers strongly preferred WebQuest-based activities over the traditional teacher-directed learning methods. The teachers believed that using WebQuests enhances students' reading skills and also helps in exploring the attitudes of students towards reading practices via WebQuests. The findings clearly showed that the reading skills of those students who had received WebQuests-based training had improved compared to the ones who did not receive such training. The students provided positive feedback about using WebQuest through the online survey.

Alshumaimeri and Almasri (2012) investigated the impact of WebQuests on the reading and comprehension performance of EFL students in Saudi Arabia. During the study, the students were exposed to various online resources through WebQuests, which allowed them to gather information related to a specific topic. The results revealed that WebQuests can be used to promote reading comprehension in the students but that the teachers and students need proper training to use WebQuests more effectively. Leung and Unal (2013) identified that WebQuests serves as the source of motivation and fun for the students; they further revealed that they promote computer literacy, accommodate diverse learning needs, and develop critical thinking skills in students. It has also been proven that WebQuests can be designed by teacher trainers for modelling the instructional practice in pre-service and in-service teachers.

Aydin (2016) conducted a review to examine WebQuests as tools for foreign language-learning processes and second-language acquisition for guiding teachers in teaching activities. The study introduced theoretical background behind WebQuest use and examined this tool as foreign language-learning processes and 
second-language acquisition. The results demonstrated that the use of WebQuest improves interaction, critical thinking, knowledge application, social skills, communication, learning, problem-solving skills, and higher order thinking skills (Aydin, 2016). Further, it helps in acquiring linguistic knowledge in a secure atmosphere, with positive impact on reading skills and vocabulary knowledge.

WebQuests has attained great deal of attention in the recent years with adequate preparation related to the understanding of the tool in teaching topological concepts for undergraduate level students. The development of WebQuest is associated with great number of topological concepts, like countability, infinity, and sets. Goktepe-Yildiz and Goktepe-Korpeoglu (2016) evaluated the usability of WebQuest considering the view of students. The results showed that pre-service teachers were interested in learning about the new technology-aided activity, along with the opportunities to be used in their further lessons.

There is significant impact blended learning on English speaking/listening and comprehension abilities of students. There was need to search for effectiveness of blended learning when it is applied in EFL classroom. Ginaya et al. (2018) investigated the impact of blended learning on the speaking ability of students as one of the language production skills. The results concluded that the speaking and writing proficiency of the third-semester students at the vocational college improve after implementing blended learning. This improvement is also supported by applying WebQuest active-learning activities that result in active interaction during the entire process of learning. Therefore, WebQuests can be used as an alternative technique or activities in English class, as the creativity in designing fun and dynamic communicative activities among teachers would stimulate their learning interest and motivation.

\section{Method}

\subsection{Study Design}

The current study used a pre-test-post-test quasi-experimental control group research design which is used extensively in educational research. The members of the control group received the traditional supervision during their teaching practice whereas the members of the experimental group received WebQuests as supplementary activities. The significant differences in teaching performance and skills between the control and the experimental groups were determined in order to evaluate the effectiveness of WebQuests.

\subsection{Participants and Context}

The study recruited 35 students of the second semester of the general diploma in the English program of the academic year 2018. The experimental group consisted of 16 students, who were exposed to the use of WebQuests during their teaching practices, while the control group comprised 19 students, who were supervised in a traditional way during their teaching practices.

\subsection{Instrumentation}

A 25-item observation form was devised to assess the teaching performance of the study sample. The teaching practice observation form dealt with three dimensions which represent the three major teaching skills addressed by the researcher. These skills are listed as follows: planning skills ( 7 items), implementation skills (13 items), and evaluation skills (5 items). Each statement was weighed on the basis of a 4-point scale ( $1=$ Poor; $2=$ Good; 3 = Very Good; $4=$ Excellent). The maximum score of the first dimension ( 7 items) was 7 x $4=28$. Similarly, the maximum score of the second dimension ( 13 items) was $13 \times 4=52$, and that of the third dimension ( 5 items) was $5 \times 4=20$. Each dimension was tested for reliability by using Cronbach's alpha, and the Cronbach alpha coefficients for dimensions 1 to 4 were between 0.91 and 0.93 indicating satisfactory levels of reliability for all the dimensions. The inter-rater reliability of the observation was determined through the Pearson Correlation Formula by administering the observation sheet to eight randomly selected general diploma students of King Khalid University attending their practicum course. The teaching performance of these participants was observed by the researcher and one of his colleagues (a faculty staff member, of the college of education, King Khalid University). The observers obtained mean scores, and the calculated value of the correlation coefficient was 0.95 which was acceptable.

\subsection{Materials}

Three WebQuests were designed in the current study. The devised WebQuests were reviewed by a panel of experts in curriculum and instruction that comprised members of the educational technology faculty for the validity of the content. Each WebQuest consisted of two pages: one page was for the student, and the other was for the teacher. The student's page included five sections:

- The introduction: to give general information about the whole WebQuest to the participants. 
- The task: to explain what is required by the participants.

- The process: detailed steps of the participants' performances.

- The evaluation: to explain certain points accomplished on completion of the task.

- The conclusion: to provide further information and links to websites to participants who wished to read more about a specific topic.

Instructions were given for the teachers who wished to use WebQuests. The examples of the topics and websites the researcher selected for the WebQuests are as follows:

- How to write an effective lesson plan?

- How to achieve your lesson objectives?

- A model lessons.

- Keeping my classroom interactive.

- Questions in the English language classroom.

- How to make your lesson enjoyable?

- No more tears: evaluation and home assignment.

Examples of the websites given in the WebQuests utilized by the study sample are as follows:

- Sites for effective lesson planning:

- http://www.ksbe.edu/_assets/spi/pdfs/21_century_skills_full.pdf

- https://lincs.ed.gov/sites/default/files/8_TEAL_Lesson_Planning.pdf

- http://www.wwcc.wy.edu/facres/tfs/focalites/lessonplan_focalite.pdf

- https://www.youtube.com/watch?v=tZmJbwhy-Ek

- https://www.youtube.com/watch?v=iE0Um3LeQUU

- https://www.youtube.com/watch?v=71GX8mndu5w

- https://www.youtube.com/watch?v=jS9uvVm9ot4

- http://www.lcnv.org/sites/default/files/pdf/Effective_Lesson_Planning_CAELA_Guide_-_Ad apted_pdf

- Sites for effective classroom practices:

- https://www.youtube.com/watch?v=vNVtd1FlXnI

- https://www.youtube.com/watch?v=k79CHITnGaw

- https://www.youtube.com/watch?v=00sRVmZa_zg

- https://www.youtube.com/watch?v=k79CHITnGaw

- http://www.p21.org/storage/documents/aacte_p21_whitepaper2010.pdf

- https://www.youtube.com/watch?v=vvlR7o81×2Q

- https://www.youtube.com/watch?v=Evf1PDyj88M

- https://www.suttontrust.com/wp-content/uploads/2014/10/What-makes-great-teaching-FINAL4.11.14.pdf

- https://www.youtube.com/watch?v=SfyBApCF41c

- https://www.youtube.com/watch?v=SfyBApCF41c

- Sites for effective teaching evaluation:

- https://www.youtube.com/watch?v=WeC_j3AhbZU

- https://www.youtube.com/watch?v=KvnpvxLZXzM

- https://www.youtube.com/watch?v=ysDDfG-enCc

- https://www.youtube.com/watch?v=uYygEN-Gcok

- http://examination.irantvto.ir/uploads/assessing_and_evaluating_student_learning.pdf 
- http://www.bgcdsb.org/UserFiles/Servers/Server_5912063/File/NTIP/Ministry\%20docs/Plan_a ssess_evaluate.pdf

- https:/my.laureate.net/Faculty/docs/Faculty\%20Documents/INTI\%20Conferences/Parallel\%2 0Sessions\%204/4C/4C-03-P142\%20(Iran).pdf

\subsection{Collection}

The data were collected via classroom observation and were subsequently analyzed using SPSS. During the 14-week study period, the teachers of the experimental group were supervised and were instructed in accordance with the researcher-designed WebQuests, which were embedded as supplementary materials during their field teaching practice. The teachers of the control group taught in the traditional way and were supervised to give feedback accordingly. The teachers of both the experimental and the control group were observed three times by four faculty members. The Mann-Whitney $U$ test was used to calculate the differences between the teachers of both the groups in terms of the teaching skills. Generally, this test is considered as the nonparametric alternative to the independent t-test. This helps in drawing different conclusions regarding data focusing on whether the two populations differ in medians between groups.

\section{Data Analysis}

The current study has shown the positive impact of using WebQuests on the teaching skills of the pre-service teachers teaching English at King Khalid University. The study has also compared the scores obtained from the control and the experimental groups. The significant differences in the post observation scores of the experimental and the control groups in the teaching performance observation form were calculated through a Mann-Whitney $U$ test (Table 1). The results show that there was a statistically significant difference between the scores of the teachers of the control and the experimental groups with respect to their lesson planning skills, and the finding favored the teachers of the experimental group. The mean ranks calculated for the experimental and the control groups were (27.50) and (10.00) respectively. The calculated z-value was -5.920 . These results indicate that the teachers of the experimental group performed much better in the lesson planning skills in comparison with the control group.

Table 1. Results of Mann-Whitney U test

\begin{tabular}{|c|c|c|c|c|c|c|}
\hline & & \multicolumn{2}{|l|}{ Group } & \multirow{2}{*}{$\begin{array}{l}\text { Mann-Whitney } \\
\text { U }\end{array}$} & \multirow[t]{2}{*}{ Z } & \multirow[t]{2}{*}{ Asymp. Sig } \\
\hline & & Experimental Group & Control Group & & & \\
\hline \multirow[t]{3}{*}{ Planning } & $\mathrm{N}$ & 16 & 19 & 0 & -5.092 & 0 \\
\hline & Mean Rank & 27.5 & 10 & & & \\
\hline & Sum of Ranks & 440 & 190 & & & \\
\hline \multirow[t]{3}{*}{ Practices } & $\mathrm{N}$ & 16 & 19 & 0 & -5.08 & 0 \\
\hline & Sum of Ranks & 27.5 & 10 & & & \\
\hline & Mean Rank & 440 & 190 & & & \\
\hline \multirow[t]{3}{*}{ Evaluation } & $\mathrm{N}$ & 16 & 19 & 149 & -0.104 & 0.917 \\
\hline & Mean Rank & 17.81 & 18.16 & & & \\
\hline & Sum of Ranks & 285 & 345 & & & \\
\hline \multirow[t]{3}{*}{ Total Skills } & $\mathrm{N}$ & 16 & 19 & 0 & -5.039 & 0 \\
\hline & Mean Rank & 27.5 & 10 & & & \\
\hline & Sum of Ranks & 440 & 190 & & & \\
\hline
\end{tabular}

The result has also shown a statistically significant difference between the scores obtained by the teachers of the control and the experimental groups with respect to lesson practice skills, and the finding favored the experimental group. The mean ranks calculated for the experimental and the control groups were (27.50) and (10.00) respectively; however, the calculated z-value was -5.08. This indicated that the subjects of the experimental group performed much better in lesson practice skills. The results also showed a statistically significant difference between the scores of the teachers of the control and the experimental groups with respect to total teaching performance skills, and the finding also favored the experimental group. Mean ranks obtained by the experimental and the control groups were (27.50) and (10.00) respectively and the calculated z-value was -5.39 . This indicated that the teachers of the experimental group performed much better in the lesson teaching performance skills in comparison with the teachers of the control group.

However, the results depicted a statistically insignificant difference between the scores obtained by the teachers of the control and the experimental groups with respect to the lesson evaluation skill. The mean scores obtained 
by the experimental and the control groups were (17.81) and (18.16) respectively, and the calculated z-value was 0.104 , which indicated that the teachers of the control and the experimental groups performed at nearly the same level and showed no significant difference.

\section{Findings and Discussion}

The results of the current study showed that there was a statistically significant difference between the mean scores of the control and the experimental groups considering the teaching performance observation form. Results of the existing study were in favor the experimental group. Use of the Mann-Whitney U test indicated that there were significant differences in the post-observation scores of the control and the experimental groups through the teaching performance observation form. Statistically significant differences were observed between the control and the experimental groups with respect to lesson planning skills, classroom practices, and total teaching performance skills; however, no significant difference was observed with respect to the evaluation skills of both the groups.

The study results have shown that the teachers of the control group had a positive impact on the development of their teaching performance skills when they were supervised via traditional methods of observation. However, the use of WebQuests had a much greater impact on the development of these skills in the teachers of the experimental group since WebQuests offered an effective, self-paced, and interactive learning environment. The findings of the current study are in line with several of the previous studies that particularly discussed the usage of the internet in teacher education programs (Kelly, 2000; Milson \& Downey, 2001; Strickland \& Nazzal, 2005; Hassanien, 2006; Little, 2007; Schweizer \& Kossow, 2007; Sheerin, 2014; Asunka, 2016; Barnard-Ashton, van der Linde, Rothberg, \& McInerney, 2018). The researcher attributed the much greater development of teaching performance skills in the teachers of the experimental group to WebQuests, which is likely to provide time-flexible, self-paced, unbound, convenient learning, and opportunities for the students of the general diploma in English.

WebQuest used links to essential resources on the World Wide Web as a scaffolded learning structure (March, 2004). This approach is responsible for motivating students in transforming newly acquired information into a sophisticated understanding. The WebQuest model has been incorporated into hundreds of education courses and staff development efforts around the globe since it was first developed in 1995 by Bernie Dodge with Tom March (Dodge, 1995). WebQuests can contextualize learning in a variety of meaningful ways, and this feature makes the model even more valuable (Asunka, 2016).

WebQuests help in the integration of technology in education. The WebQuests model is studied with respect to its effectiveness in the field of education in Saudi Arabia in order to investigate its impact on developing the TEFLers' teaching performance. To address the scarcity of studies found in the literature, the current study highlighted the impact of utilizing WebQuests in the practicum. Metacognitive knowledge that enhances the awareness of students and helps them become conscious about learning process as well as of their weaknesses and strengths is greatly emphasized by the WebQuests model because it is a learner-based approach (Sadaghian \& Susan, 2016). Learners are given an opportunity to plan and negotiate, to do project work, to evaluate their learning in a cyclic mode, and to make decisions through an idea and activity bank at the top of a work cycle. According to the findings of the current study, WebQuests play an important role in developing learner autonomy, as they encourage critical thinking in the learners.

Kundu and Bain (2006) described the facilitation provided by WebQuests in a constructivist manner to adopt an active role in the learning process. Learning is facilitated as an organic process by the use of constructivist learning methods, which offers meaningful learning after the resolution of and reflection on a cognitive conflict. Students are allowed to think reflectively, making an authentic connection between the learning and the real world, and have multiple solutions through constructivist methods. The authenticity of WebQuests is proved through the cooperation and collaborative association aimed to produce knowledge.

WebQuests play an important role in the enrichment of resources and class interaction, and also encourage the intellectual development of students. Indeed, computers and the internet have a significant impact on student learning, as they provide lively illustrations and familiar settings for learners which make learning easy (Selinger, 2009; Ahmad, 2016).

\section{Conclusion}

The low level of teaching performance skills of pre-service teachers was the driving force behind this study, which aimed to find the solution to this problem by using WebQuests. In a similar context, the current study aimed to investigate the impact of WebQuests on the development of the teaching performance skills of the 
pre-service teachers. The results showed the significant positive impact of using WebQuests on the teaching performance skills of the students of the general diploma in English. Hence, there is an urgent need to train university students about how to use WebQuests effectively in blended learning classrooms. The changing pedagogical principles and practices that are emerging by the use of tool cause inherent changes after the implementation of WebQuests. Students in their transmitting mode of instruction require support to understand and adjust to the new way of learning. Therefore, teachers need to understand that their role has changed from being an authoritative teacher to being a facilitator/mentor on account of the designs of WebQuests.

The teachers are recommended to use WebQuests as language-learning tool in second and foreign language-learning processes, along with inquiry-based, cooperative, autonomous, and constructivist learning approaches. This tool should also be used in language learning for the acquisition and contextualization of linguistic knowledge, which plays an important role in enhancing comprehensible input by paying attention towards supplying comprehensible input for learners during WebQuest. There is further need to be aware about less positive perceptions of activities administered on WebQuests among second language learners, as compared to the traditional activities. Further, it is recommended that development of WebQuests help the teacher to focus on two specific areas; pedagogy and scholarship, rather than just focusing on characteristics that specifically foster second-language acquisition and foreign language learning.

Therefore, teachers are recommended to incorporate WebQuests into teacher training programs and implement them within textbooks to provide knowledge and skills for teaching and solving instructional problems and integrate technology into their classrooms. University students are required to improve their skills in order to use WebQuests more effectively in their learning. Moreover, the teachers need to be made aware of the importance of students' learning autonomy. Future studies should conduct similar research but for other courses to investigate the effectiveness of WebQuests in developing other skills. Moreover, future studies should also focus on the training program, along with the implementation of WebQuests for faculty teachers of the university.

\section{Acknowledgements}

The authors extend their appreciation to the Deanship of Scientific Research at King Khalid University for funding this work through General Research Project under grant number [grant numbers R.G.P.1/66/40, 2018]. Further, this research holds no conflict of interest and is not funded through any source.

\section{References}

Abbitt, J., \& Ophus, J. (2008). What we know about the impacts of WebQuests: A review of research. AACE Journal, 16(4), 441-456.

Abdullah, H. M. A. (2018). Using Scenario-Based Learning for Pre-Service EFL Teacher Preparation. Journal of the Faculty of Education in Educational Sciences, 42(1), 83-123. https://doi.org/10.21608/jfees.2018.79284

Adell, J., Mengual-Andrés, S., \& Roig-Vila, R. (2015). Presentation of the Monographic. WebQuest: 20 years using the Internet as a resource for the classroom. Edutec. Electronic Journal of Educational Technology, 52, a298. https://doi.org/10.21556/edutec.2004.17

Ahmad, J. (2016). Technology Assisted Language Learning is a silver bullet for enhancing Language competence and performance: A Case Study. International Journal of Applied Linguistics and English Literature, 5(7), 118-131. https://doi.org/10.7575/aiac.ijalel.v.5n.7p.118

Akkoyunlu, B., \& Yilmaz, M. (2005). Information Literacy Levels of Pre-service Teachers, Frequency of Internet Usage and Internet Usage Purposes. Eurasian Journal of Educational Research (EJER), 19, 1-4.

Alshumaimeri, Y. A., \& Almasri, M. M. (2012). The effects of using WebQuests on reading comprehension performance of Saudi EFL students. Turkish Online Journal of Educational Technology (TOJET), 11(4), $295-306$.

Asunka, S. (2016). Fostering Effective Student Engagement in a First Year University Course by Harmonizing Web-based Resources with Interaction: The WebQuest Approach. Journal of Advances in Business and Management Research (JABMAR), 3(1), 1-34.

Aydin, S. (2016). WebQuests as language-learning tools. Computer Assisted Language Learning, 29(4), 765-778. https://doi.org/10.1080/09588221.2015.1061019

Barnard-Ashton, P., van der Linde, J., Rothberg, A., \& McInerney, P. (2018). First-year students' experience of a WebQuest to explore the University's online resources and virtual learning environment. South African Journal of Occupational Therapy, 48(2), 3-11. https://doi.org/10.17159/23103833/2018/vol48n2a2 
Bergen, D. (2001). Technology in the Classroom: Differentiating Curriculum with Technology-Enhanced Class Projects. Childhood Education, 78(2), 117-118. https://doi.org/10.1080/00094056.2002.10522719

Cochran-Smith, M. (2016). Teaching and teacher education: Absence and presence in AERA presidential addresses. Educational Researcher, 45(2), 92-99. https://doi.org/10.3102/0013189X16639040

Coffey, A., \& Lavery, S. (2015). Service-learning: A valuable means of preparing pre-service teachers for a teaching practicum. Australian Journal of Teacher Education, 40(7), n7. https://doi.org/10.14221/ajte.2015v40n7.7

Dodge, B. (1995). WebQuests: A technique for internet-based learning. Distance Educator, 1(2), 10-13.

Gaskill, M., McNulty, A., \& Brooks, D. W. (2006). Learning from WebQuests. Journal of Science Education and Technology, 15(2), 133-136. https://doi.org/10.1007/s10956-006-9005-7

Ginaya, G., Rejeki, I. N. M., \& Astuti, N. N. S. (2018). The effects of blended learning to students' speaking ability. International Journal of Linguistics, Literature and Culture, 4(3), 1-14. https://doi.org/10.21744/ijllc.v4i3.661

Goktepe-Yildiz, S., \& Goktepe-Korpeoglu, S. (2016). A sample Webquest applicable in teaching topological concepts. International Journal of Education in Mathematics, Science and Technology, 4(2), 133-146. https://doi.org/10.18404/ijemst.35581

Haddix, M. M. (2017). Diversifying teaching and teacher education: Beyond rhetoric and toward real change. Journal of Literacy Research, 49(1), 141-149. https://doi.org/10.1177/1086296X16683422

Hassanien, A. (2006). An evaluation of the WebQuest as a computer - based learning tool. Research in Post-Compulsory Education, 11(2), 235-250. https://doi.org/10.1080/13596740600769230

Irafahmi, D. T. (2016). Creating a 'real' WebQuest: Instructional design point of view. International Journal of Education and Research, 4(2), 427-438.

Kachina, O. A. (2012). Using WebQuests in the Social Sciences Classroom. Contemporary Issues in Education Research, 5(3), 185-200. https://doi.org/10.19030/cier.v5i3.7095

Kelly, R. (2000). Working with WebQuests: Making the web accessible to students with disabilities. Teaching Exceptional Children, 32(6), 4-13. https://doi.org/10.1177/004005990003200601

Kim, Y. (2011). Developing a Model of Effective English Teaching for Pre-Service Teacher Education. Retrieved from https://eric.ed.gov/?id=ED520808

Kundu, R., \& Bain, C. (2006). WebQuests: Utilizing technology in a constructivist manner to facilitate meaningful preservice learning. https://doi.org/10.1080/00043125.2006.11651581

Kushins, J. (2015). Pedagogical Souvenirs: An Art Educator's Reflections on Field Trips as Professional Development. International Journal of Education \& the Arts, 16(20).

Leung, C. B., \& Unal, Z. (2013). Advantages and Disadvantages of Classroom Instruction with WebQuests: Connecting Literacy and Technology. Journal of Reading Education, 38(2).

Little, D. (2007). Language learner autonomy: Some fundamental considerations revisited. International Journal of Innovation in Language Learning and Teaching, 1(1), 14-29. https://doi.org/10.2167/illt040.0

Maddux, C. D., \& Cummings, R. (2007, June). WebQuests: Are they developmentally appropriate? In The Educational Forum (Vol. 71, No. 2, pp. 117-127). Taylor \& Francis Group. https://doi.org/10.1080/00131720708984925

March, T. (2004). The learning power of WebQuests. Educational Leadership, 61(4), 42-47.

Milson, A. J. (2002). The Internet and inquiry learning: Integrating medium and method in a sixth-grade social studies classroom. Theory \& Research in Social Education, 30(3), 330-353. https://doi.org/10.1080/00933104.2002.10473200

Milson, A. J., \& Downey, P. (2001). WebQuest: Using Internet resources for cooperative inquiry.

Richards, J. C. (2008). Second language teacher education today. RELC Journal, 39(2), 158-177. https://doi.org/10.1177/0033688208092182

Sadaghian, S., \& Marandi, S. S. (2016). Using WebQuests as idea banks for fostering autonomy in online language courses. CALL communities and culture - short papers from EUROCALL 2016 Edited by Salomi Papadima-Sophocleous, Linda Bradley, and Sylvie Thouësny, 403. 
https://doi.org/10.14705/rpnet.2016.eurocall2016.596

Sadik, O., Leftwich, A. O., \& Nadiruzzaman, H. (2017). Computational thinking conceptions and misconceptions: Progression of preservice teacher thinking during computer science lesson planning. In Emerging research, practice, and policy on computational thinking (pp. 221-238). Springer, Cham. https://doi.org/10.1007/978-3-319-52691-1_14

Schrum, L. (2005). Technology as a tool to support instruction. Education World.

Schweizer, H., \& Kossow, B. (2007). WebQuests: Tools for differentiation. Gifted Child Today, 30(1), 29-35. https://doi.org/10.4219/gct-2007-19

Selinger, M. (2009). ICT in education: Catalyst for development (pp. 206-248). ICT4D: Information and communication technology for development.

Sheerin, S. (2014). An exploration of the relationship between self-access and independent learning. In Autonomy and independence in language learning ( $\mathrm{pp}$. 54-65). Routledge. https://doi.org/10.4324/9781315842172-5

Skott, J. (2015). The promises, problems, and prospects of research on teachers' beliefs. International Handbook of Research on Teachers'Beliefs, 1, 37-54.

Strickland, J., \& Nazzal, A. (2005). Using WebQuests to teach content: Comparing instructional strategies. Contemporary Issues in Technology and Teacher Education, 5(2), 138-148.

Wang, F., \& Hannafin, M. J. (2008). Integrating WebQuests in preservice teacher education. Educational Media International, 45(1), 59-73. https://doi.org/10.1080/09523980701847214

Yang, C. H., Tzuo, P. W., \& Komara, C. (2011). WebQuests and collaborative learning in teacher preparation: A

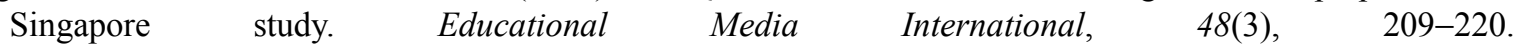
https://doi.org/10.1080/09523987.2011.607325

Yüksel, H. G. (2014). Becoming a teacher: tracing changes in pre-service English as a foreign language teachers' sense of efficacy. South African Journal of Education, 34(3). https://doi.org/10.15700/201409161104

\section{Copyrights}

Copyright for this article is retained by the author, with first publication rights granted to the journal.

This is an open-access article distributed under the terms and conditions of the Creative Commons Attribution license (http://creativecommons.org/licenses/by/4.0/). 